BERKELEY, CALIFORNIA

CIRCULAR No. 283

APrIL, 1925

\title{
FERTILIZING CITRUS TREES \\ IN CALIFORNIA
}

By ROBERT W. HODGSON

\section{INTRODUCTION}

The annual fertilizer bill of the California citrus fruit growers reaches a total of several million dollars. Surveys indicate that expenditures for fertilizers constitute the largest item in the average citrus orchard management programme, amounting to about sixty dollars per acre per year. They are in many cases higher, not infrequently amounting to as much as one hundred and fifty dollars. These expenditures are relatively large as compared to the practice in other fruit growing industries and indicate that the citrus fruit growers of this state are convinced of the necessity and importance of fertilization as an aid to profitable production. It is believed that there is ample evidence available, however, to warrant the statement that by exercising more discrimination in the selection of fertilizers in accordance with our present knowledge of their effects on citrus trees, the same general results might be had from much smaller expenditures. 'It is certain that many citrus growers purchase large amounts of fertilizers which, so far as our present knowledge goes, do not pay returns on the investment. It is equally certain that by a greater use of certain fertilizers, many growers might materially increase their orchard yields with profit.

For some eighteen years the California Agricultural Experiment Station has been conducting fertilizer tests with citrus trees. ${ }^{*}$ Among the most important of these have been the trials at the Rubidoux site of the Citrus Experiment Station, the Arlington tests, and fertilizer

* The list of workers contributing materially to our knowledge of citrus fertilization in California includes the following: Ralph E. Smith, J. W. Mills, T. Francis Hunt, J. H. Norton, J. Eliot Coit, H. J. Webber, W. M. Mertz, W. P. Kelley, R. S. Vaile, C. J. Booth, Gordon Surr, and J. A. Prizer. 
experiments at Ontario, Chula Vista, and Naranjo. A number of surveys relating to fertilizer practice have also been made. It is the purpose of this circular to present a brief summary of our present knowledge of this important subject, and recommendations based on the work done by this station. The data used in compiling the present publication have already been presented in bulletins, technical papers, and addresses before groups of citrus growers.*

The form of presentation followed will be the answering of the questions most commonly raised by the growers which for convenience, are set forth as follows :

1. Do citrus trees require fertilization?

2. What plant food elements and other materials supplied by fertilizers produce measurable increases in yield or improvements in the quality of the fruit?

3. How much nitrogen per tree gives the best results?

4. What forms of nitrogen fertilizers give the best results?

5. How much of the nitrogen should be supplied in bulky organic form?

6. What are the comparative availabilities of the different nitrogen fertilizers and of what practical importance are these differences?

7. When should the different nitrogen fertilizers be applied for the best results?

8. What methods of application are recommended?

9. What is the fertilizer value of a covercrop?

10. What are the values of lime, gypsum, sulfur, and other soil amendments ?

11. What is the value of peat?

12. How should fertilizers be selected and purchased?

1. In California citrus trees require fertilization if crop production is to be maintained.

In the early years of the citrus industry in California the only guide available to growers was experience and practice elsewhere. It was known that the use of considerable quantities of fertilizers was the practice in Florida and in the citrus districts of the old world. The natural assumption, therefore, was that in all probability the citrus orchards in California would require fertilization. Within a few years experience was accumulated substantiating this assumption. It was commonly observed that the fertilized orchards generally were more productive than those not fertilized. It was further noted that it

* A list of the more important papers and bulletins dealing with this subject will be found at the end of this paper. 
frequently required a period of eight or ten years before these differences became evident, but this was readily explainable on the basis of the high initial fertility of the soil in many of the older citrus districts.

Although quantitative data in sufficient amount to establish the necessity for fertilization in the commercial production of citrus fruits was lacking, by 1900 this requirement was generally accepted by growers and investigators. Since that time, however, ample evidence to establish this point beyond question has been accumulated.

In 1907 a survey of fertilizer practice in some fifty citrus orchards in southern California furnished consistent data showing that the fertilized orchards were higher in yield than the unfertilized orchards. In 1913 a report on the Rubidoux trials, established in 1907, called attention to the fact that unfertilized trees at six and seven years of age had already failed to produce satisfactory crops. From that time on the differences became much more marked in the Rubidoux plots and after reaching ten years of age as reported in 1922, the unfertilized trees bore practically no fruit. That the necessity for fertilizing citrus trees had been fully demonstrated is one of the conclusions set forth in the general summary of citrus fertilizer trials in California published in 1922. It may therefore be said without qualification that for the economical and profitable production of citrus fruits in California, fertilization is required.

2. Nitrogen is the only element and organic matter the only other material which have been demonstrated to give measurable improvements in yield and tree health. The application of phosphorus or potassium has not been shown to be necessary or beneficial.

Experience developed in the older agricultural sections of the world, and particularly in the humid regions has led to the conclusion that nitrogen, phosphorus and potassium are the elements most likely to be exhausted in cropped soils. The assumption of the necessity of adding these in order to maintain crop production has furnished the basis for fertilizer practice the world over. Attention was early directed to nitrogen as the probable limiting factor in crop production on California soils, extensive studies indicating that this element is of primary importance and that organic matter is likewise an essential in maintaining crop production. The conclusion was also reached that phosphorus is the element of second importance and that only rarely is potassium needed.

In order to gain more exact information as to the different elements required in the fertilization of citrus trees and also to compare differ- 
ent sources of these elements, the Citrus Experiment Station in 1907 established at Riverside the Rubidoux fertilizer experiment, already referred to. This experiment has contributed much to our knowledge of citrus fertilization. In the original experiment there were 20 plots, to which two more were added later. The three plant food nutrients were applied separately and in various combinations, and the experiment was arranged in such a manner as to make possible comparisons not only between the different elements but also between various carriers of these elements. The carriers of nitrogen were given especial attention.

Nitrogen.-Although for ten or fifteen years before the establishment of the Rubidoux experiment it had been felt that high yields were correlated with the use of nitrogenous fertilizers or fertilizers high in nitrogen content, specific data on this point were not forthcoming until the results of the Rubidoux experiment began to develop. Within a few years after the experiment was established, outstanding effects from the use of nitrogen fertilizers became apparent.

The first report on this experiment, made in 1913, states that at that time, when the trees were six and seven years old, the only measurable increases in production had been secured from the nitrogen plots. In 1914, the results of coöperative fertilizer tests maintained at Santa Paula, Riverside and Pomona, were reported with the statement that the tests showed unmistakable results from the use of nitrogenous fertilizers. In 1915, a fertilizer practice survey conducted in the Ontario-Upland district revealed a strong correlation between high yields and the use of relatively large amounts of nitrogen. The 1920 report on the results of the Arlington experiment, established by the Citrus Experiment Station in 1915, states that the plots receiving commercial fertilizers high in nitrogen had shown a marked response in increased production the first season of application and these plots had continued to show measurable increases in yield during the fiveyear period of the experiment. The 1922 summary of results on the Rubidoux plots states that the trials there had demonstrated conclusively that nitrogen is the main limiting plant food element.

In the summary of all citrus fertilizer tests, in the same report, the general conclusion is advanced that in all cases where it had been possible to make comparisons or to analyze the results, measurable increases in production were always associated with the use of nitrogen.

Organic matter.-The fundamental importance of organic matter in the soil has of course been recognized almost from the beginnings of agriculture, and from ancient times tillage and cropping practices 
designed to assist in the maintenance of a high content of organic matter have been recognized as an essential feature of good farm practice. The importance of organic matter in California soils was early emphasized and it has long been known that in addition to its nitrogen content there are other important reasons for its beneficial effects in the soil.

While the importance of organic matter was long ago recognized by the citrus growers and large quantities have been used for many years, it was not until comparatively recently that quantitative data were secured demonstrating its necessity and importance in citrus fertilization. As early as 1900, the Experiment Station recommended the use of large quantities of organic matter in the fertilization of citrus trees. Quantitative data bearing on this question did not become available, however, until supplied by the Rubidoux tests. Observations made by various members of the Experiment Station show that from practically the beginning, in 1907, the plots on which manure was applied, either with or without a winter covercrop, were equal to those receiving concentrated nitrogenous fertilizers. Within a few years it became apparent that the plots receiving organic matter were superior to certain of the concentrated nitrogen-fertilized plots and this superiority continued to develop until by 1920 , by general agreement, they were regarded as clearly superior to all other plots in the experiment. In 1922 these plots still maintained their superiority as shown in the report published in that year.

Reporting on the effects of organic matter furnished by covercrops, in 1918 data were submitted showing striking increases in yield and much better health of trees on the covercropped plots than on the plots fertilized with manure alone. The 1920 report on the Arlington tests indicated that the trees on the plots receiving only manure, in comparison to those receiving large quantities of nitrogen from chemical sources, were in much the best condition after five years, although second in yield. Since that time, although additional applications were not made, the manure plots have consistently ranked first in both yield and tree condition.

In the summary of all the citrus fertilizer tests published in 1922, the conclusion is advanced that bulky organic matter has always shown pronounced beneficial results, when furnished either in the form of manure alone or with the addition of the winter covercrop. Striking evidence on this point has recently been brought out in a survey of six hundred citrus fruit orchards, which will be referred to later under another heading. It is therefore clear that the substantial benefit from the use of decomposable organic matter in citrus fertilization has been 
well established on the basis of quantitative data accumulated during many years. The cumulative effects of its use serve to emphasize the importance of annual applications of this kind of material.

Phosphorus and Potassium.-The so-called ready-mixed complete fertilizers containing the three plant nutrients, nitrogen, phosphorus, and potassium, came into prominence early in the history of the citrus industry in California, and were used extensively, especially after agreement had been reached to the effect that fertilization was a profitable practice. The proponents of the use of these fertilizers, however, while usually willing to admit the importance of nitrogen, almost from the beginning have claimed special benefits from their use. Among these claims have been improvements in eating and keeping quality of the fruit, the former principally by increase in sugar content and the production of a smoother and thinner rind, and the latter by imparting unusual powers of resistance to decay producing organisms. The advocates of the use of potassium have been especially active in advancing claims of these benefits and in addition have always held that this element materially increases the resistance of citrus trees to frost injury. Claims of increased yields attendant upon the use of these elements have also been advanced, though not so much in recent years as formerly. The necessity of a "balanced ration" for citrus trees is also an argument much used by the proponents for the complete fertilizer.

While thousands of tons of ready-mixed complete fertilizers have been purchased by the citrus growers on the basis of these claims, analysis of the fertilizer tests on citrus trees in this state furnishes little evidence to support the arguments of benefits from the application of phosphorus or potassium, singly, together, or in combination with nitrogen.

Although applications of phosphorus and potassium had been made for six years, in 1913 no measurable improvements from the use of these elements had been noted in the Rubidoux plots. The 1914 report on the coöperative field trials at Santa Paula, Riverside and Pomona, previously referred to, states that they furnished no evidence indicating benefits from the use of phosphorus or potassium. In one experiment where potassium alone was tested, the results were reported as entirely negative. In the summary of the Rubidoux plots made in 1922 , it is stated that the plots receiving phosphorus or potassium or both, but no nitrogen, had shown no significant differences in yield or other characters from the unfertilized plots, and advanced the conclusion that no evidence whatever had been secured to show that the use of either of these elements had increased yield or improved quality. 
The summary of the Arlington fertilizer plots given in the same report, states that since the best fruit had been produced on plots receiving nitrogen only, there was no evidence that phosphorus or potassium are essential for the production of citrus fruits of good quality. The general summary of all citrus fertilizer work done in California, issued in 1922, concludes that no positive evidence of benefits from the use of these two elements has yet been shown. Additional evidence to support these general conclusions has been secured from the Chaffey fertilizer plots. The 1923 report on these plots states that as yet there is no evidence of increases of yield from the use of these elements and that the best fruit in the experiments has been produced on plots not receiving either.

So far as composition of the fruit is concerned, it is interesting to note that the only measurable effect thus far noted has been a slight influence of nitrogen in the Rubidoux trials, which was reported in 1917 to have resulted in a slightly lower amount of sugar, a somewhat coarser fruit, and a little less juice. These differences, however, had in no case resulted in lowering the commercial grade of the fruit.

It is readily admitted, however, that the data available concerning the specific effects of the different plant nutrients upon the fruit, and especially upon its keeping and shipping quality, are meager. More data are required before final conclusions on these points can be drawn with certainty. Further studies of these questions are now being outlined.

While there is no doubt that citrus trees require phosphorus and potassium, it appears that these are either already available in sufficient amounts in California soils, or are made available as needed by the decomposition of organic materials. Moreover, it should be pointed out that the use of animal manures provides relatively large amounts of these two elements. There is certainly as yet no experimental evidence whatever that phosphorus and potassium can take the place of organic matter or that applications of these elements have proved necessary or beneficial.

3. From two to three pounds of nitrogen per tree per year is ordinarily the most profitable amount of this element, although larger amounts may produce more fruit.

With a growing recognition of nitrogen as the principal plant nutrient required in citrus fertilization, the question of how much nitrogen should be used to maintain the trees in good health and production becomes one of importance, as is also the inquiry as to the amount of nitrogen it is profitable to apply. Wide variation exists in 
the amount of nitrogen used. When the ready-mixed complete fertilizers were used extensively, the average amount of nitrogen furnished was about one pound per tree. As it became apparent that this element was responsible for the increased production, in many cases the amounts used were increased materially, although usually without reference to supplying any definite quantity per tree. In a general way the range in the use of this element has been from 1 to 5 pounds per tree.

Measurable increases in yield have frequently been noted from the use of relatively small amounts of nitrogen, from 0.5 to 1 pound per tree, and one pound per tree has been the basis of much citrus fertilizer practice. Data from tests bearing on this point, however, are comparatively meager. The nitrogen plots in the Rubidoux experiment, were fertilized at the rate of 1.28 pounds per tree. The nitrogen plots in the Arlington experiment received approximately 1.5 pounds per tree. In 1921 tests were established at Ontario in which 1, 2, and 3 pounds per tree were compared, and at about the same time the farm advisors in several counties established similar trials.

In 1922 and 1923 an extensive survey on the use of nitrogen was conducted, in which the yields of six hundred citrus orchards for a period of five years were analyzed on the basis of the amount of nitrogen applied annually during that period as correlated with yield. The results of this survey constitute by far the most comprehensive data available bearing on this point, and show that there is a regular increase in yield where amounts of nitrogen are used up to 350 pounds per acre, approximately 4 pounds per tree. It should be emphasized, however, that an unhealthy condition of the trees was shown to be correlated with the use of this quantity of nitrogen. The general conclusion was reached that the most profitable amount of this element to use lies betwen 250 and 300 pounds per acre when the price received for the fruit averages two cents per pound or better. When lower prices prevailed the most profitable use of nitrogen appeared to be from 150 to 250 pounds per acre.

In 1924 data were reported showing that two pounds per tree had been the most profitable use of this element in the Chaffey experiments, although three pounds was the most productive use. It is believed that the evidence now available is sufficient to indicate rather definitely that about 200 pounds per acre of nitrogen is the most profitable amount for young bearing trees and about 300 pounds for the older trees. How much of the different nitrogenous fertilizers is required to supply these amounts is shown in Table 1. 
4. No one source of nitrogen has been shown to be best but the evidence is conclusive that part of it should be supplied in bulky organic form.

Ever since the importance of nitrogen has been recognized, citrus fruit growers have held individual preferences as to sources of this element. Rather definite beliefs have existed that certain nitrogenous fertilizers are better than others, although there has never been any

\section{TABLE 1}

Nitrogen Content of Different Fertilizers and Amounts Required to Supply 200 Pounds of Nitrogen Per ACre

\begin{tabular}{|c|c|c|c|}
\hline \multirow{2}{*}{ Nitrogenous fertilizers } & \multirow{2}{*}{$\begin{array}{l}\text { Average } \\
\text { nitrogen } \\
\text { content in } \\
\text { percent }\end{array}$} & \multicolumn{2}{|c|}{$\begin{array}{l}\text { Amount required to supply } \\
200 \mathrm{lbs} \text {. }\end{array}$} \\
\hline & & Per acre & Per tree* \\
\hline Alfalfa hay.... & 2.0 & 5 tons & $125 \mathrm{lbs}$. \\
\hline 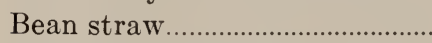 & 1.5 & 6.6 tons & 167 lbs. \\
\hline Ordinary manures........... & 0.5 & 20.0 tons & $500 \mathrm{lbs}$. \\
\hline High grade manures......... & 1.5 & - 6.6 tons & 167 lbs. \\
\hline Nitrate of soda.... & 15.0 & $1333 \mathrm{lbs}$. & $16.6 \mathrm{lbs}$. \\
\hline 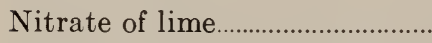 & 12.0 & $1667 \mathrm{lbs}$. & $20.8 \mathrm{lbs}$. \\
\hline Sulfate of ammonia................... & 20.0 & $1000 \mathrm{lbs}$. & $12.5 \mathrm{lbs}$. \\
\hline Bone meal......................... & 3.0 & $6667 \mathrm{lbs}$. & $83.3 \mathrm{lbs}$. \\
\hline Low grade tankage...... & 5.0 & $4000 \mathrm{lbs}$. & $50.0 \mathrm{lbs}$ \\
\hline Garbage tankage.......... & 2.5 & 8000 lbs. & $100.0 \mathrm{lbs}$. \\
\hline High grade tankage...... & 9.0 & $2222 \mathrm{lbs}$. & $27.7 \mathrm{lbs}$. \\
\hline Cottonseed meal.............. & 6.0 & 3333 lbs. & $41.6 \mathrm{lbs}$. \\
\hline 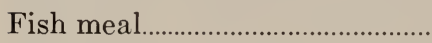 & 10.0 & $2000 \mathrm{lbs}$. & $25.0 \mathrm{lbs}$. \\
\hline Dried blood............ & 12.0 & $1667 \mathrm{lbs}$. & $20.8 \mathrm{lbs}$. \\
\hline
\end{tabular}

For converting tons into cubic measure a value of 35 to 40 pounds per cubic foot for clean and relatively dry manure may be used.

* On basis of eighty trees to the acre.

general agreement as to which is best. The evidence available at the present time indicates that nitrogen from one source is quite as effective as that from any other, provided the total amounts supplied are the same and the rates of decomposition and methods of application such as to make it available to the trees in equal quantities at the same time. Study of the various tests thus far conducted indicates the impossibility of deriving any general conclusions with reference to the best source of nitrogen. In respect to yield, health of trees, and quality of fruit, the best results within the different individual fertilizer tests have frequently been secured by nitrogen from different sources. 
Thus, the general summary of citrus fertilizer results published in 1922, concludes that no source of nitrogen has been found to be the best and, comparing the plots in which nitrogen was applied in chemical form, in the form of high grade organic fertilizers, and in complete fertilizers, states that the results have been similar. Again, the 1923 report on the Chaffey plots indicates fluctuations back and forth in reference to the source of nitrogen which gave the best results.

The evidence that at least a part of the nitrogen used can be supplied with advantage from bulky organic sources is overwhelming, as indicated previously in the discussion of the necessity of organic matter. Thus the superior condition of the manure-covercrop plots at Rubidoux has been recognized for many years and would certainly indicate that a part, if not all, of the nitrogen should be in bulky organic form.

The same conclusion is reached in the general summary of fertilizer work with citrus trees, namely, that bulky organic matter has always shown beneficial results, manure being always to be regarded as a good source of a large part of the nitrogen, and alfalfa hay and bean straw being also excellent sources of this element.

5. The evidence available at this time indicates that at least half of the nitrogen should be supplied from bulky organic sources. With bearing trees there is evidence to indicate that a part of the nitrogen can be supplied in concentrated form with advantage.

By far the most comprehensive data bearing on the proportion of the nitrogen used which can be supplied with advantage from bulky organic sources, are furnished by the extensive survey, already referred to, on citrus orchard fertilizer practices. In this survey a positive correlation was established between yield and amount of nitrogen applied in the form of manure. It was shown, on the basis of the practice followed by many hundreds of growers, that high yields are definitely associated with the use of large amounts of manure, up to 20 tons per acre. Arbitrarily setting a figure of 100 as the average yield of the orchards in which 60 per cent or more of the nitrogen was applied in bulky organic form, it was found that in the orchards where this source supplied only from 40 to 60 per cent the relative yield was 93, and in orchards where less than 40 per cent of the nitrogen came from bulky sources, 89. On the basis of tons of manure applied per acre, it was shown that the relative yield of orchards where less than five tons were applied was 86, as compared to 100 for the highest yielding class where from fifteen to twenty tons were used.

The observation made by many growers as well as by Station workers that applications of quickly available nitrogen in the spring 
frequently occasion a heavier set of fruit, is supported by the positive results on this point in the Arlington experiment. This indicates, that while bulky organic sources alone are much superior to chemical sources or to organic concentrates alone, it is probable that a combination of the two will be found most advantageous. Thus the 1922 summary states that it would appear that the combination of manure or covercrop with some high grade source of nitrogen is better than either alone. Corroboration of these results has also been furnished in the five-year soil management tests in Tulare County, conducted by the Citrus Experiment Station.

The conclusion seems warranted therefore that for the bearing orchard, at least one-half the nitrogen used should be furnished by bulky organic materials and the rest by quickly available concentrates.

6. The nitrogenous fertilizers may be divided into two groups-those quickly available, and those slowly available. Choice between these groups depends principally upon time of application.

Availability may be defined as the rate at which the plant nutrients in a soil or fertilizer are released and converted into forms in which plants can use them. With the nitrogenous fertilizers, this form is believed to be chiefly nitrates. The importance of availability is related primarily to the time of application of the fertilizers. Thus a quickly available fertilizer should be applied close to the period when it is required by the plant, and conversely, a slowly available fertilizer should be applied some time before it is required, in order that it may have sufficient time to pass through the processes which render it available. While there are wide variations in availability in the nitrogenous fertilizers, studies made by the Experiment Station in recent years indicate that these gradations are not so marked as was formerly believed and that it is possible to establish two general classes-the quickly available sorts, and those more slowly available.

From.the standpoint of nitrogen content a further classification of the nitrogenous fertilizers into two principal groups, the bulky organic materials and the concentrates, is convenient. The concentrates are further divided according to source, into the inorganic (chemical) forms and organic forms. Investigations have shown that in general the bulky organies are slowly available although there are several exceptions, including alfalfa hay, green manure crops (covererops), and poultry manure, which are to be regarded as fairly quickly available. Bean straw is perhaps the slowest of the bulky organies to become available and barnyard manure intermediate in position. Barley straw has been shown to be not only extremely slowly available but for long periods specifically depressive to the nitrifying bacteria 
in the soil. The use of this material therefore is advised against, except for the improvement of the physical condition of very heavy soils. Manures high in cereal straw content may therefore be regarded as in general very slowly available and sometimes depressive to nitrification.

Although slight differences exist, the concentrates are all fairly quickly available. Two of the chemical forms now on the market, nitrate of soda and nitrate of lime, being already in the nitrate form, are immediately available and do not require transformation in the soil. The others must be nitrified in the soil and this will take more or less time up to several weeks, according largely to the temperature and moisture conditions.

Nitrate of Soda.-Especial reference should be made to the use of nitrate of soda as a source of quickly available nitrogen for citrus trees. The markedly injurious effects noted in the Rubidoux plots where nitrate of soda alone has been used as a source of nitrogen have been regarded as at least reflecting suspicion on this fertilizer. It is by no means certain, however, that other chemical sources of nitrogen might not have produced equally unfavorable results if they had been used in a similar manner. On fairly open, porous soils where the drainage is good so as to prevent the accumulation of the sodium residue from this fertilizer, there appears to be little reason for anticipating injurious effects from its use, especially if applied in reasonable amounts in conjunction with large quantities of organic materials.

A general classification of the nitrogenous fertilizers according to content of nitrogen and availability is as follows:

(1) Bulky organic (0.5 to 2.5 per cent nitrogen).

$$
\begin{gathered}
\text { Slowly available }\left\{\begin{array}{l}
\text { Bean straw } \\
\text { Animal manures } \\
\text { Dry cover crops } \\
\text { Garbage tankage }
\end{array}\right. \\
\text { Quickly available }\left\{\begin{array}{l}
\text { Alfalfa hay } \\
\text { Poultry manure } \\
\text { Green manure crops }
\end{array}\right.
\end{gathered}
$$

(2) Concentrates (2 to 20 per cent nitrogen).

All quickly available

$$
\begin{aligned}
& \text { Inorganic (chemical) }\left\{\begin{array}{l}
\text { Nitrate of soda } \\
\text { Nitrate of lime } \\
\text { Sulfate of ammonia }
\end{array}\right. \\
& \text { Organic }\left\{\begin{array}{l}
\text { Dried blood } \\
\text { Cottonseed meal } \\
\text { High and low grade tankages } \\
\text { Fish scrap or meal } \\
\text { Whale meat } \\
\text { Bone meal }
\end{array}\right.
\end{aligned}
$$


7. In general the bulky organic materials, with the exception of the quickly available forms, should be applied in the fall. The concentrates, on the other hand, should be applied in the spring.

As was brought out in the discussion concerning availability, the slowly available fertilizers should be applied some time in advance of the period when the nutrients they contain are needed. In the case of bean straw this may and usually does require three or four months, with barnyard manure perhaps a slightly shorter time, and with alfalfa hay a feiv weeks. The question of when to apply the nitrogenous fertilizers is dependent, therefore, upon a knowledge of the period when needs of the plants for nitrogen are greatest. While undoubtedly citrus trees require some nitrogen throughout the entire year, there appears to be a fairly definite period when this nutrient is of special importance. With orchard fruits in general this is believed to be just before and during the blooming and fruit-setting period. It is of special interest to note that at this period the amount of soil nitrates in citrus orchards is frequently comparatively low.

There is ample observational evidence as well as considerable experimental evidence to indicate that with citrus trees the most marked response to the use of nitrogenous fertilizers is secured when these are applied so as to furnish available nitrogen during the blooming and fruit-setting period. The Arlington experiments and numerous others have furnished positive evidence in support of this conclusion.

In general therefore, the quickly available fertilizers should be applied in the spring, preferably at the time of plowing if this is not delayed until too close to the period of bloom, and for the best results the more slowly available forms should be applied in the fall.

\section{Deep application where possible, preferably by plowing, is recom-} mended.

It cannot be said that any one method of applying fertilizers to citrus trees has been shown to be superior to all others. Whatever the method used, the main object should be to place the fertilizers where the feeder roots can utilize them. Avoidance of losses of organic matter from excessive oxidation incident to cultivation and of nitrates from leaching, are also factors of importance in determining the method of application. Since the feeder roots are located below the surface mulch, it is important that the method of application be such as to insure the placement of fertilizers below that zone. To accomplish this with the bulky organic materials requires deep incorporation, and this should preferably be done by plowing deep. If surface applications of these materials are to be made, the best season for so doing 
is the winter months, when a minimum amount of cultivation is practiced and oxidation losses of organic matter therefore lightest. This practice is not recommended for the heavy soils in districts where spring rains are normally heavy, however, on account of the tendency to keep the soil wet and cold which materially depresses nitrate formation. Reasons of convenience frequently require the application of organic materials at other seasons of the year and where this is necessary it is important that they be immediately incorporated as deeply in the soil as it is feasible under the circumstances.

With reference to the application of organic materials in deep furrows or trenches, it appears that this method is especially beneficial for young trees and in older orchards where the tillage and fertilizer practice has been such as to encourage surface feeding. In the case of young trees, each year the furrows should be moved farther out so as to overcome any tendency toward restriction in root distribution. In the older orchards this method is suggested only as an occasional practice to supplement surface distribution and deep incorporation of these materials.

In a similar way the concentrates should preferably be placed deep in the soil, with the possible exception of late winter or early spring applications of the chemical forms which are readily carried down by rain. Experience indicates that the application of concentrates on the surface or in shallow furrows is a wasteful practice since under the usual furrow irrigation method employed the nitrates are rather quickly concentrated in the surface mulch. Therefore plowing down such fertilizers or applying them in deep irrigation furrows is recommended.

9. The winter covercrop has a pronounced fertilizer value in the young citrus orchard and in the older orchard, a replacement value of three to five tons of manure.

So far as the value of the covercrop is concerned, the principal data available have to do with the leguminous winter covercrop. Under favorable conditions the late summer covercrop may have a positive fertilizer value, especially in the young orchard, but in the bearing orchard factors entering into its management are so complex that it is doubtful whether they can be satisfactorily controlled. Experience and observation have indicated that, under many conditions at least, the growing of a summer covercrop in the citrus orchard is a practice of doubtful value.

In the young orchard the fertilizer value of the winter covercrop is unquestionably high as has been brought out strikingly in work done 
at the Citrus Experiment Station and reported on in 1918. This work indicates conclusively that in the young orchard the covererop is a means of greatly stimulating growth and production. The pronounced value of covercrops has also been shown in the young orchard at the new Experiment Station site. The trees were planted in 1917 and at the present time, eight years later, this orchard is generally regarded as considerably above the average for its age. No fertilizers have been applied and its present condition is believed to be largely due to the effects of the winter and summer covercrops grown.

In the bearing citrus orchard the covercrop is unquestionably of considerable value where a reasonable tonnage can be grown without competition with the trees. The data from the tests on older orchards, however, are conflicting, the probable explanation of which is competition with the trees either for nitrogen or water.

The orchard practice survey previously referred to brings out clearly the fact that in the bearing orchard the covercrop has a definite organic-matter replacement value. Where the smallest amounts of manure were used, it was shown that the covercrop gave the most striking results, with an average increase in yield of about 20 per cent. Where the largest amounts of manure were used, the least effect from the covercrop was noted in an increased yield of 6 per cent. A good covercrop consisting of 12 to 15 tons of green material should furnish approximately two tons of dry matter, each of which is equivalent in fertilizer value (nitrogen and organic matter) to two tons of ordinary manure. We do not know how much of the nitrogen in the covercrop is taken directly from the soil nor is it known how much nitrogen is added to the soil by the bacteria in the nodules on the roots of the covercrop. The relative proportions of these two undoubtedly vary considerably. On the basis of the general considerations presented, however, it is believed that there is justification for estimating the covercrop replacement value at from three to five tons of manure.

10. The use of lime, gypsum, sulfur, and other soil amendments is rarely productive of measurable benefits.

The evidence with reference to the use of soil amendments is fragmentary and in some cases conflicting. In most of the tests, however, these materials have given negative results. In one or two tests there have been slight indications of benefits from the application of lime and gypsum. The 1922 summary of results of fertilizer tests with citrus trees states that five years of lime applications on the Arlington plots had shown no benefits whatever. The same conclusion has been reached by a number of the farm advisors from tests conducted in their counties. 
The citrus tree has a high calcium content, however, as shown by studies at the Citrus Experiment Station, and recent investigations indicate that the absence of this element from the soil solution quickly brings about a condition of disease. On the other hand we know that there are practically no acid soils in California citrus districts and from hundreds of analyses, it has been shown that citrus soils are in general quite high in calcium. In addition there is considerable evidence to show that the decomposition of organic matter in the soil has much to do with making calcium available. At the present time we can only conclude that the use of lime is rarely productive of measurable improvements.

The same may be said with reference to gypsum, sulfur, and other soil amendments. Where the citrus grower wishes to use these materials it is recommended that they be applied on a few rows only, with untreated trees left to afford a measure of possible benefits.

11. Peat cannot be regarded as a satisfactory manure substitute since little or none of its nitrogen is available and its organic matter is not readily decomposed.

The occurrence of extensive peat deposits adjacent to the citrus districts in many parts of California has been responsible for recurrent exploitations of this material as a fertilizer for citrus trees. On account of its similarity in composition to barnyard manure the tendency has been to exploit it on the basis of a manure substitute, especially when inoculated with various bacterial cultures.

Studies made by the Experiment Station during recent years, however, have shown rather conclusively that the available nitrogen content of peat is very small and that the organic material in this substance is decomposed with great difficulty if at all, in California soils. Experiments in which peat has been applied in amounts sufficient to supply two hundred pounds of nitrogen per acre have failed to show significent improvements in yield or other characteristics.

It would appear, therefore, that whatever benefit if any, is to be derived from the use of this material must be altogether from its effect on the physical condition of the soil, and obviously the amounts required to produce such an influence are so great as to render its use impracticable in nearly all cases. If peat could be obtained at no cost, it is doubtful whether it would be worth hauling any great distance to the orchard.

In any event it is certain that peat, treated or otherwise, cannot be regarded as a fertilizer for citrus trees, and by no means as a substitute for manure or other sources of decomposable organic matter. 
12. Fertilizers should be purchased on the basis of their unit costs for the plant nutrients desired. In the case of the concentrates, nitrogen is the effective constituent; in the bulky organic materials, nitrogen and organic matter.

A number of factors may enter into the choice of fertilizers, among which are the materials available on the market, the time when the fertilizers are to be applied, the fertilizer programme followed, the market price per unit for the plant nutrients, and others. As already indicated, it is believed that on bearing trees at least half of the nitrogen should be applied in bulky organic form, and the remainder in the form of concentrates. With the latter, other things being equal, a choice of materials should be based on the comparative cost per unit of nitrogen, and in the case of the former, the cost of the organic matter in addition.

The concentrates are now generally sold on the unit basis, at prices which vary widely according to demand and supply. Prices are generally quoted on the unit basis, the unit being 1 per cent of a ton or 20 pounds. With some of these materials, however, the practice of quoting them on the cost per ton is still followed. Where this is done the cost per unit should be computed by dividing the ton cost by the nitrogen content in per cent. On account of the wide variation in prices for these materials, by the exercise of a little discrimination in choice, the opportunity is afforded for effecting material saving in

TABLE 2

Variation in Costs of Fertilizers, Per Ton, Per Pound, and on Basis of Amounts Required to Yield 11/4 Pounds of Nitrogen per Tree

(100 POUNDS PER ACRE)

\begin{tabular}{|c|c|c|c|c|c|}
\hline Fertilizers & $\begin{array}{c}\text { Nitrogen } \\
\text { content } \\
\text { in } \\
\text { percent }\end{array}$ & $\begin{array}{c}\text { Price } \\
\text { per ton* }\end{array}$ & $\begin{array}{l}\text { Price } \\
\text { per pound } \\
\text { in cents }\end{array}$ & $\begin{array}{l}\text { Pounds to } \\
\text { supply } \\
1 \frac{1}{4} \text { pounds } \\
\text { nitrogen }\end{array}$ & $\begin{array}{l}\text { Cost (in } \\
\text { cents) of } \\
\text { amount } \\
\text { to yield 1! } \\
\text { pounds } \\
\text { nitrogen }\end{array}$ \\
\hline 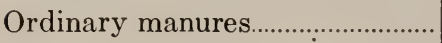 & 0.5 & $\$ 4.50$ & 0.225 & 250.0 & 56.25 \\
\hline 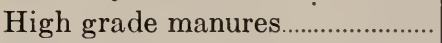 & 1.5 & 13.50 & 0.675 & 83.3 & 56.23 \\
\hline 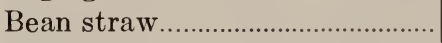 & 1.5 & 16.00 & 0.8 & 83.3 & 66.64 \\
\hline Alfalfa hay.......... & 2.0 & 30.00 & 1.5 & 62.5 & 93.75 \\
\hline Nitrate of soda........... & 15.0 & 55.00 & 2.75 & 8.3 & 22.83 \\
\hline Nitrate of lime................ & 12.0 & 60.00 & 3.0 & 10.4 & 31.20 \\
\hline Sulfate of ammonia................ & 20.0 & 67.00 & 3.35 & 6.2 & 20.77 \\
\hline High grade tankage........... & 9.0 & 53.00 & 2.65 & 13.8 & 36.57 \\
\hline Cottonseed meal............ & 6.0 & 47.50 & 2.37 & 20.8 & 49. 10 \\
\hline Fish meal & 10.0 & 53.00 & 2.65 & 12.5 & 33.13 \\
\hline 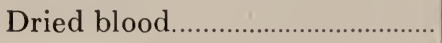 & 12.0 & 65.00 & 3.25 & 10.4 & 33.80 \\
\hline
\end{tabular}

*As of November 1, 1924. 
TABLE 3

Variation in Costs per Tree for Fertilizer Combinations Yielding 21/2 Pounds of Nitrogen,* One-Hilf from Bulkx Organic Sources, the REMAINDER FROM CONCENTRATES

\begin{tabular}{|c|c|c|c|c|}
\hline \multirow{2}{*}{ Concentrates } & \multicolumn{4}{|c|}{ Bulky organics } \\
\hline & $\begin{array}{l}\text { Ordinary } \\
\text { manures }\end{array}$ & $\begin{array}{l}\text { High grade } \\
\text { manures }\end{array}$ & $\begin{array}{l}\text { Bean } \\
\text { straw }\end{array}$ & $\begin{array}{c}\text { Alfalfa } \\
\text { hay }\end{array}$ \\
\hline Nitrate of soda........... & $\$ 0.79$ & $\$ 0.79$ & $\$ 0.89$ & $\$ 1.17$ \\
\hline Nitrate of lime............ & .88 & .87 & .98 & 1.25 \\
\hline Sulfate of ammonia... & .77 & .77 & .87 & 1.15 \\
\hline High grade tankage. & .93 & .93 & 1.03 & 1.30 \\
\hline Cottonseed meal........ & 1.05 & 1.05 & 1.16 & 1.41 \\
\hline 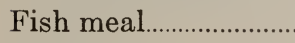 & .89 & .89 & .99 & 1.27 \\
\hline Dried blood.. & .90 & .90 & 1.00 & 1.28 \\
\hline
\end{tabular}

* At the rate of 200 pounds per acre.

costs. An idea of the extent of the variation in cost which normally occurs, and of the possibility of economizing in the purchase of fertilizers may be gained from tables 2 and 3 .

Other things being equal, the cheapest nitrogen and organic matter should be purchased, provided of course that the latter is of a character readily decomposable in the soil. Organic matter of a leguminous source such as manure derived largely from nitrogenous feeds (alfalfa hay, cottonseed cake, etc.), alfalfa hay, or bean straw, are usually more desirable than organic matter high in cellulose (cereal straws, etc.). Of the concentrates, the chemical carriers are usually the cheapest. Thus, if cottonseed meal, with an analysis of 6 per cent nitrogen is quoted at $\$ 42$ per ton, the cost per unit for this element will be $\$ 7$ or 35 cents per pound. If sulfate of ammonia, analyzing 20 per cent, is quoted at $\$ 70$ per ton, the cost per unit will be $\$ 3.50$, or just half that of the cottonseed meal. In this case therefore it would certainly be economical to use the chemical source for that part of the total nitrogen to be supplied from concentrates.

Since the bulky organic fertilizers are valuable chiefly for nitrogen and organic matter, their cost should be calculated on this basis and this practice is rapidly coming into use. The organic matter in such materials is usually quoted at prices ranging from four to six cents per unit. Thus bean straw analyzing at 11/2 per cent nitrogen and 80 per cent organic matter would be worth for nitrogen at $\$ 5$ per unit $\$ 7.50$, and for organic matter at 5 cents per unit $\$ 4$, or a total of $\$ 11.50$ per ton. 


\section{EXPERIENCE IN ORCHARD FRUIT FERTILIZATION}

During the past twenty years, the fertilization of fruit trees has received much attention at the hands of experiment station workers in various parts of the United States from the Pacific coast to the Atlantic seaboard. While the results in some cases have been conflictory, in the words of a recent worker, summarizing the various experiments, "there is, however, general agreement in some respects : potash applications have almost without exception resulted in no increase, wherever tried; phosphorus applications have been almost as uniformly unproductive. The one element that has stood out conspicuously, where fertilization has proved profitable, is nitrogen." In the cases where potassium and phosphorus have been reported as beneficial, almost without exception it has been in connection with the growth of covercrops. Observations of the effects of these elements on the growth of covercrops in citrus orchards in California as yet have failed to furnish indications of substantial benefits, the results being negative in nearly all cases.

\section{THE SOIL MANAGEMENT PROGRAMME AND FERTILIZATION}

Experience in California and elsewhere indicates a close relation between the soil management programme and the effects obtained from the application of fertilizers. The results of tests in other states have led some investigators to the conclusion that the system of soil management used is of more importance than the fertilizer programme followed. While it is possible that this may be true under certain conditions the evidence with reference to citrus trees in California does not fully support this conclusion.

It is certain, however, that the soil management programme may overcome or at least partially mask the effects of good fertilizer practice. This has been brought out in a striking manner in a five-year test of soil management practices in citrus orchards in Central California where immediate and marked differences in yield and tree conditions were shown even though the plant nutrients and amounts of water applied were practically the same. It is clearly evident from this experiment as well as from observation and experience that the soil management programme should be outlined and conducted so as to supplement the fertilizer practice followed, as it is only where this is done that maximum results from expenditures for fertilizers are obtained. 
Among the soil management practices believed to materially affect the efficiency of the fertilizer programme are time and depth of plowing down the covercrop in the spring, and the irrigation practice, especially in the spring and early summer months. The irrigation and cultural practices should be such that the soil warms up early in the spring and the roots are amply supplied with available nitrates. This can be accomplished only by a proper combination between the soil management programme and the fertilizer practice, and without this combination the maximum results from the fertilizer programme cannot be expected.

\section{SUMMARY}

1. In California, citrus trees require fertilization if crop production is to be maintained.

2. Nitrogen is the only element and organic matter the only other material which have been demonstrated to give measurable improvements in yield and tree health.

3. The application of phosphorus or potassium has not been shown to be necessary or beneficial.

4. From two to three pounds of nitrogen per tree per year is ordinarily the most profitable use of this element, although larger amounts may produce more fruit.

5. No one source of nitrogen has been shown to be best but the evidence is conclusive that part of it should be supplied in bulky organic form.

6. The evidence available at this time indicates that at least half of the nitrogen should be supplied from bulky organic sources.

7. With bearing trees there is evidence to indicate that a part of the nitrogen ean be supplied with advantage in concentrated form.

8. The nitrogenous fertilizers may be divided into two groupsthose quickly available to the trees, and those slowly available. Choice between these groups depends principally upon the time of application.

9. In general the bulky organic materials, with the exception of the quickly available forms, should be applied in the fall.

10. The concentrates, on the other hand, should be applied in the spring.

11. Deep application where possible, preferably by plowing, is recommended. 
12. The winter covercrop has a pronounced fertilizer value in the young citrus orchard and in the older orcharr, a replacement value of three to five tons of manure.

13. The use of lime, gypsum, sulfur, and other soil amendments is rarely productive of measurable benefits.

14. Peat cannot be regarded as a satisfactory manure substitute since little or none of its nitrogen is available and its organic matter is not readily decomposed.

15. Fertilizers should be purchased on the basis of their unit cost for the plant nutrients desired. In the case of the concentrates, nitrogen is the effective constituent; in the bulky organic materials, nitrogen and organic matter.

16. As reported by recognized authorities, the general fertilizer experience with orchard fruits in the United States is similar to that with citrus fruits in California, measurable improvements being associated almost invariably with the use of organic matter and nitrogen.

17. The soil management and fertilizer programmes should supplement each other if maximum benefits are to be derived from expenditures for fertilizers.

\section{THE FERTILIZER PROGRAMME IN THE CITRUS ORCHARD}

1. In the young orchard grow covercrops (winter always, late summer if possible) but keep them under control. This treatment alone is usually sufficient for the first seven or eight years.

2. For young bearing trees grow a winter covercrop and apply bulky organic materials to supply a total of two pounds of nitrogen per tree per year. This treatment should suffice until the trees are 12 to 15 years old.

3. From this time on apply two to three pounds of nitrogen per tree, approximately half of which should be from bulky organic sources and the remainder from concentrates.

4. Use lime and other soil amendments only where trials show definite measurable improvement in tree health or yield. 


\section{LIST OF THE MORE IMPORTANT PUBLICATIONS DEALING WITH FERTILIZER RESULTS APPLICABLE TO CITRUS TREES IN CALIFORNIA}

Alderman, W. H.

1922. The present status of orchard fertilization. Kansas State Hort. Soc. Biennial Report 36: 126-129.

Воотн, C. J.

1923. Report on Chaffey fertilizer experiments. California Citrograph 8:

BURD, J. S. pp. $387,397$.

1918. Peat as a manure substitute. California Agr. Exp. Sta. Circ. 203: $1-10$.

Kelley, W. P.

1917. Nitrification in California soils. California Citrograph 2: no. 8, pp. 7, 14, 15.

1917. The fertilization of citrus. California Agr. Exp. Sta. Circ. 171: 1-4. 1922. Our present knowledge concerning fertilization of citrus. California Citrograph 7: pp. 186, 202.

LipMan, C. B., and WANK, M. E.

1924. The availability of nitrogen in peat. Soil Sci. 18: 311-316.

McBeth, I. G., and Allison, J. R.

1919. Necessity for manure standardization. California Citrograph 4: 259, $278,279$.

Mertz, W. M.

1918. The use of green manure crops in southern California. California VAILE, R. S. Agr. Exp. Sta. Bull. 292: 1-31.

1914. Review of practical experiments in fertilization. Proc. 45th Calif. Fruit Growers' Convention, Los Angeles, Nov. 10-14, 1914, pp. 135-136. Also in Monthly Bull. California State Com. Hort. 3: 501-503.

1921. Progress report on Arlington grove experiment. California Citrograph 6: 44, 66, 67. Dec. 1920. Also in Second Ann. Report California Citrus Institute, pp. 8-16.

1922. Fertilizer experiments with citrus trees. California Agr. Exp. Sta. Bull. 345: 465-512.

1924. A survey of orchard practices in the citrus industry of southern California. California Agr. Exp. Sta. Bull. 374: 4-40.

WEBEER, H. J.

1913. Fertilizer experiments with citrus fruits. California Cultivator 41: 596.

1914-1915. The fertilizer requirements of citrus trees. Proc. 45th Calif. Fruit Growers' Convention, Los Angeles, Nov. 10-14, 1914, pp. 101-106. Also in Monthly Bull. California State Com. Hort. 4: 225-230. 1915.

Young, H. D.

1917. Effect of fertilizers on the composition and quality of oranges. Jour. Agr. Research 8: 127-138. 


\section{BULLETINS}

No.

253. Irrigation and Soil Conditions in the Sierra Nevada Foothills, California.

261. Melaxuma of the Walnut, "Juglans regia."

262. Citrus Diseases of Florida and Cuba Compared with Those of California.

263. Size Grades for Ripe Olives.

268. Growing and Grafting Olive Seedlings.

273. Preliminary Report on Kearney Vineyard Experimental Drain.

275. The Cultivation of Belladonna in California.

276. The Pomegranate.

277. Sudan Grass

278. Grain Sorghums.

279. Irrigation of Rice in California.

280 . Irrigation of Alfalfa in the Sacramento $\checkmark$ alley.

283. The Olive Insects of California.

285. The Milk Goat in California.

286. Commercial Fertilizers.

294. Bean Culture in California.

304. A Study of the Effects of Freezes on Citrus in California.

310. Plum Pollination.

312. Mariout Barley.

313. Pruning Young Deciduous Fruit Trees.

319. Caprifigs and Caprification.

324. Storage of Perishable Fruit at Freezing Temperatures.

325. Rice Irrigation Measurements and Experiments in Sacramento Valley, 1914-1919.

328. Prune Growing in California.

331. Phylloxera-Resistant Stocks.

334. Preliminary Volume Tables for SecondGrowth Redwood.

335. Cocoanut Meal as a Feed for Dairy Cows and Other Livestock.

339. The Relative Cost of Making Logs from Small and Large Timber.

340. Control of the Pocket Gopher in California.

343. Cheese Pests and Their Control

344. Cold Storage as an Aid to the Marketing of Plums.

346. Almond Pollination.

347. The Control of Red Spiders in Deciduous Orchards.

348. Pruning Young Olive Trees.

349. A Study of Sidedraft and Tractor Hitches.

350. Agriculture in Cut-over Redwood Lands.
No.

352. Further Experiments in Plum Pollination.

353. Bovine Infectious Abortion.

354. Results of Rice Experiments in 1922

357. A Self-mixing Dusting Machine for Applying Dry Insecticides and Fungicides.

358. Black Measles, Water Berries, and Related Vine Troubles.

359. Fruit Beverage Investigations.

361. Preliminary Yield Tables for Second Growth Redwood.

362. Dust and the Tractor Engine.

363. The Pruning of Citrus Trees in California.

364. Fungicidal Dusts for the Control of Bunt.

366. Turkish Tobacco Culture, Curing and Marketing.

367. Methods of Harvesting and Irrigation in Relation to Mouldy Walnuts.

368. Bacterial Decomposition of Olives during Pickling.

369. Comparison of Woods for Butter Boxes.

370. Browning of Yellow Newtown Apples.

371. The Relative Cost of Yarding Small and Large Timber.

372. The Cost of Producing Market Milk and Butterfat on 246 California Dairies.

374. A Survey of Orchard Practices in the Citrus Industry of Southern California.

375. Results of Rice Experiments at Cortena, 1923.

376. Sun-Drying and Dehydration of Walnuts.

377. The Cold Storage of Pears.

379. Walnut Culture in California.

380. Growth of Eucalyptus in California Plantations.

381. Growing and Handling Asparagus Crowns.

382. Pumping for Drainage in the San Joaquin Valley, California.

383. Monilia Blossom Blight (Brown Rot) of Apricot.

384. A Study of the Relative Values of Cer tain Succulent Feeds and Alfalfa Meal as Sourses of Vitamin A for Poultry.

385. Pollination of the Sweet Cherry.

386. Pruning Bearing Deciduous Fruit Trees.

\section{CIRCULARS}

No.

87. Alfalfa.

113. Correspondence Courses in Agriculture.

117. The Selection and Cost of a Small Pumping Plant.

127. House Fumigation.

129. The Control of Citrus Insects.

136. Melilotus indica as a Green-Manure Crop for California.

144. Oidium or Powdery Mildew of the Vine.

151. Feeding and Management of Hogs.

152. Some Observations on the Bulk Handling of Grain in California.

154. Irrigation Practice in Growing Small Fruit in California.
No.

155. Bovine Tuberculosis.

157. Control of the Pear Scab.

160. Lettuce Growing in California.

161. Potatoes in California.

164. Small Fruit Culture in California.

165. Fundamentals of Sugar Beet Culture under California Conditions.

166. The County Farm Bureau.

167. Feeding Strffs of Minor Importance.

170 . Fertilizing California Soils for the 1.918 Crop.

173. The Construction of the Wood-Hoop Silo.

178. The Packing of Apples in California 


\section{CIRCULARS-(Continued)}

No.

179. Factors of Importance in Producing Milk of Low Bacterial Count.

184. A Flock of Sheep on the Farm.

190. Agriculture Clubs in California.

199. Onion Growing in California.

202. County Organizations for Rural Fire Control.

203. Peat as a Manure Substitute.

208. Summary of the Annual Reports of the Farm Advisors of California.

209. The Function of the Farm Bureau.

210. Suggestions'to the Settler in California.

212. Salvaging Rain-Damaged Prunes.

214. Seed Treatment for the Prevention of Cereal Smuts.

215. Feeding Dairy Cows in California.

217. Methods for Marketing Vegetables in California.

220. Unfermented Fruit Juices.

228. Vineyard Irrigation in Arid Climates.

231. The Home Vineyard.

232. Harvesting and Handling California Cherries for Eastern Shipment.

233. Artificial Incubation.

234. Winter Injury to Young Walnut Trees during 1921-22.

235. Soil Analysis and Soil and Plant Interrelations.

236. The Common Hawks and Owls of California from the Standpoint of the Rancher.

237. Directions for the Tanning and Dressof Furs.

238. The Apricot in California.

239. Harvesting and Handling Apricots and Plums for Eastern Shipment.

240. Harvesting and Handling Pears for Eastern Shipment.

241. Harvesting and Handling Peaches for Eastern Shipment.

243. Marmalade Juice and Jelly Juice from Citrus Fruits.

244. Central Wire Bracing for Fruit Trees.

245. Vine Pruning Systems.

247. Colonization and Rural Development.

248. Some Common Errors in Vine Pruning and Their Remedies.

249. Replacing Missing Vines.

250. Measurement of Irrigation Water on the Farm.
No.

251. Recommendations Concerning the Common Diseases and Parasites of Poultry in California.

252. Supports for Vines.

253. Vineyard Plans.

254. The Use of Artificial Light to Increase Winter Egg Production.

255. Leguminous Plants as Organic Fertilizer in California Agriculture.

256. The Control of Wild Morning Glory.

257. The Small-Seeded Horse Bean.

258. Thinning Deciduous Fruits.

259. Pear By-products.

260. A Selected List of References Relating to Irrigation in California.

261. Sewing Grain Sacks.

262. Cabbage Growing in California.

263. Tomato Production in California.

264. Preliminary Essentials to Bovine Tuberculosis Control.

265. Plant Disease and Pest Control.

266. Analyzing the Citrus Orchard by Means of Simple Tree Records.

267. The Tendency of Tractors to Rise in Front; Causes and Remedies.

268. Inexpensive Lavor-saving Poultry Appliances.

269. An Orchard Brush Burner.

270. A Farm Septic Tank.

271. Brooding Chicks Artificially.

272. California Farm Tenancy and Methods of Leasing.

273. Saving the Gophered Citrus Tree.

275. Marketable California Decorative Greens.

276. Home Canning.

277. Head, Cane, and Cordon Pruning of Vines.

278. Olive Pickling in Mediterranean Countries.

279. The Preparation and Refining of Olive Oil in Southern Europe.

281. The Results of a Survey to Determine the Cost of Producing Beef in California.

282. Prevention of Insect Attack on Stored Grain.

The publications listed above may be had by addressing

College of Agriculture,

University of California, Berkeley, California. 